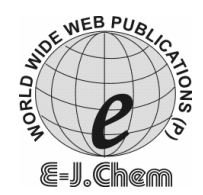

http://www.e-journals.net
ISSN: 0973-4945; CODEN ECJHAO

E-Journal of Chemistry 2009, 6(3), 880-886

\title{
Growth Kinetics of Anodic Oxide Films Formed on Zircaloy-2 in Various Electrolytes
}

\author{
V.JEEVANA JYOTHI ${ }^{*}$ and CH.ANJANEYULU \\ *Department of Chemistry, \\ R.B.V.R.R.Women's College, Narayanguda, Hyderabad, India. \\ Department of Chemistry, University College for Women, \\ Osmania University, Hyderabad-500007, India. \\ jeevana.j@rediffmail.com
}

Received 5 November 2008; Revised 13 January 2009; Accepted 5 February 2009

\begin{abstract}
The Kinetics of anodic oxidation of zircaloy- 2 have been studied at current densities ranging from 4 to $12 \mathrm{~mA} \mathrm{~cm}^{-2}$ at room temperature in order to investigate the dependence of ionic current density on the field across the oxide film. Thickness of the anodic films was estimated from capacitance data. The formation rate, current efficiency and differential field were found to increase with increase in the ionic current density for zircaloy-2. Plots of logarithm of formation rate $v s$. logarithm of current density is fairly linear. From linear plots of logarithm of ionic current density vs. differential field and applying the Cabrera - Mott theory, the half - jump distance (a) and height of energy barrier (W) were deduced.
\end{abstract}

Keywords: Anodization, Current density, Differential field, Cabrera-Mott theory, Zircaloy-2.

\section{Introduction}

When valve metals such as zirconium and its alloys like $\mathrm{Zr}-2, \mathrm{Zr}-4$, etc. are anodically polarized, interference colored oxide films is formed. These smooth and mechanically perfect anodic films can act as dielectrics in capacitors. The phenomenon of anodic oxidation plays a basic role in micro - circuitry ${ }^{1}$ and in thin film methods ${ }^{2}$. Anodic oxide films formed on valve metals are useful in the field of electrical and electronic components (such as capacitors, resistors, dioxides and photoelectric devices), corrosion protection and for decorative purposes. Applications of anodic films have been reviewed ${ }^{3}$. Guntherschultze and Betz ${ }^{4}$ were the first to investigate the kinetics and mechanism of the anodic oxidation of metals. Temperature and current density were found to exert a marked influence on the anodizing characteristics of metals ${ }^{5-8}$ such as zirconium, its alloys, niobium, halfnium, titanium etc. 
Hoar ${ }^{9}$, Young et $a l^{10}$ Vermilyea $^{11}$ and Diggle et $a l^{12}$ Panasa Reddy et al ${ }^{13}$ Lavanya $^{14}$ have reviewed the work from various view points. Radiotracer studies were also done by using labeled phosphorous $\left({ }^{32} \mathrm{P}\right)$ to understand the mechanism of anodic film formation ${ }^{15-18}$.

In the present work, an attempt is made to study the effect of current density on the kinetics of formation of oxide films on zircaloy- 2 in $0.1 \mathrm{M}$ solutions of sulphamic acid, potassium malonate and ammonium hydroxide.

\section{Experimental}

The specimen used in the present work were punched from $0.1 \mathrm{~mm}$ thick, annealed rolled sheet of zircaloy -2 supplied by the Nuclear Fuel Complex, Hyderabad as a gift sample. The specimens had a working area of $1 \mathrm{~cm}^{2}$ on each side and a tag $2 \mathrm{~cm}$ long. The specimens were polished to mirror finish by using chemical polishing mixtures, which consisted of $\mathrm{HF}$ and $\mathrm{HNO}_{3}$ in definite volume ratios.

Adams et $a l^{19-20}$ \& Willis et $a l^{21-22}$ used chemically polished specimens which gave higher values for current efficiency at higher current densities. For anodization, a closed cell of $100 \mathrm{~mL}$ Pyrex glass beaker was used. The cathode was a platinum mesh of $20 \mathrm{~cm}^{2}$ superficial area, specifically chosen to make the double layer capacitance as large as possible. The constant current generator used was a stabilized power supply unit (Powertronics, Hyderabad) capable of supplying constant current in the 0-100 mA range. Capacitance measurements were made with a digital LCR meter (Vasavi Electronics, Hyd). Current was measured on a digital milliammeter and the potential directly across the cell on a digital voltmeter. Thicknesses of the anodic films were estimated from capacitance measurements. For this, the constant current was interrupted at regular voltage increments $(20 \mathrm{~V})$ by reversing a DPDT switch. An interval of about 30 s was allowed to lapse prior to reading a capacitance data.

\section{Results and Discussion}

\section{Formation rate-current density relationship}

The kinetics of the anodic oxidation of zircaloy- 2 were studied in $0.1 \mathrm{M}$ solutions of sulphamic acid, ammonium hydroxide and potassium malonate at constant current densities ranging from 4 to $12 \mathrm{~mA} \mathrm{~cm}{ }^{-2}$ and at room temperature. The formation rate $(\mathrm{dV} / \mathrm{dt})$ was estimated from plots of formation voltage $v s$ time drawn at each current density for these electrolytes. The plots of logarithm formation rate $v s$. logarithm current density are found to be linear, as shown in Figure 1.

Values of slopes and intercepts in these plots are given in Table 1. The formation rate is expressed in $V^{-1}$ and the current density in $\mathrm{mA} \mathrm{cm} \mathrm{cm}^{-2}$. The linearity between $\log (\mathrm{dv} / \mathrm{dt})$ and $\log (\mathrm{i})$ shows that they are related by the empirical relation.

$$
\mathrm{dV} / \mathrm{dt}=\mathrm{a}(\mathrm{i})^{\mathrm{b}}
$$

Table 1. Parameters in equation (1) for $\mathrm{Zr}-2$.

\begin{tabular}{lcc}
\hline \multicolumn{1}{c}{ Electrolyte } & Slope, $\mathrm{b}$ & Intercept, log a \\
\hline Sulphamic acid & 0.98 & 2.24 \\
Ammonium hydroxide & 1.24 & 2.70 \\
Potassium malonate & 1.34 & 3.04 \\
\hline
\end{tabular}

Where, $\mathrm{a}$ and $\mathrm{b}$ are constants. A similar relationship was given by Vermilyea ${ }^{11}$ for the dependence of $\mathrm{d} \partial / \mathrm{dt}$ on $i$ for tantalum, where $\partial$ is the thickness of the oxide film. The theoretical basis for the empirical relationship was given by Ammar and $\mathrm{Kamal}^{23}$ and Lavrenko and Chekhovskii ${ }^{24}$. Ammar and $\mathrm{Kamal}^{23}$ found that the values of slopes were independent of acid concentration in $\mathrm{H}_{2} \mathrm{SO}_{4}, \mathrm{HNO}_{3}$ and $\mathrm{HCl}$, whilst in $\mathrm{H}_{3} \mathrm{PO}_{4}$ the value was 
found to vary with the acid concentration. The slopes deduced were $1.18 \mathrm{in}_{2} \mathrm{SO}_{4}, 1.26$ in $\mathrm{HNO}_{3}, 1.16$ in $\mathrm{HCl}, 1.20$ in $0.1 \mathrm{~N}$ and $1 \mathrm{~N}$ solution of $\mathrm{H}_{3} \mathrm{PO}_{4}$ and 1.34 in $5 \mathrm{~N}$ solution. Similar linear relationships were established by Anjaneyulu ${ }^{25}$ and Shyamala Devi et al ${ }^{26}$ for Ti in electrolytes such as propionic acid and ammonium citrate. Raghunath Reddy et $a l^{7}$ got similar linear relationships for zircaloy-4 and Niobium in electrolytes such as mandalic acid, ammonium borate and potassium hydroxide

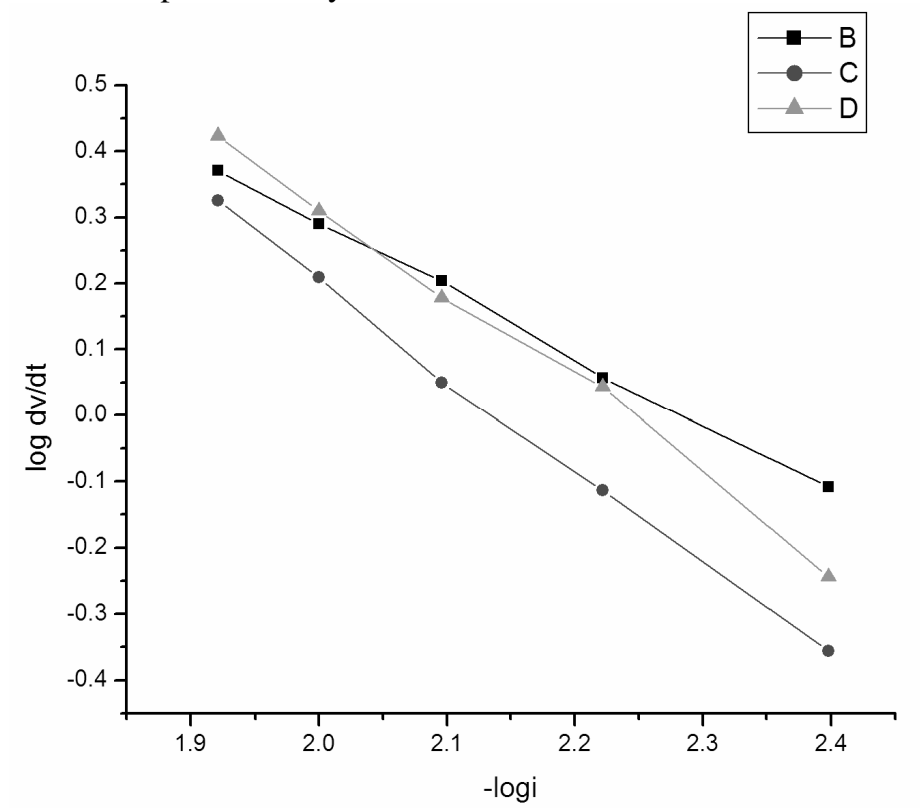

Figure 1. Variation of formation rate $(\mathrm{dV} / \mathrm{dt})$ with current density (i) $B=$ Sulphamic acid $C=$ Potassium malonate $D=$ Ammonium hydroxide

\section{Ionic current density and differential field strength}

The growth kinetics involves the study of variation of differential field with the ionic current density and calculation of kinetic parameters half-jump distance (a) and height of energy barrier (W) assuming that the rate determining step lies at the interfaces or within the bulk of the oxide. In the present study it was assumed that the highest energy barriers are situated at the interfaces and that the Cabrera-Mott type theory was applicable. From plots of formation voltage $v s$. time and reciprocal capacitances $v s$. time, the formation rate $(\mathrm{dV} / \mathrm{dt})$, current efficiency $(\eta)$, Ionic current density $\left(\mathrm{i}_{\mathrm{i}}\right.$ ) and differential field (F.D) were calculated for zircaloy- 2 in the three electrolytes (Table 2, 3, 4). The current efficiency and field strength can be seen to be increasing with the increase in current density. Plots of logarithm ionic current density $\left(\mathrm{i}_{\mathrm{i}}\right) v s$. differential field (F.D) were drawn for each current density and were found to be fairly linear as shown in Figure 2. Using the empirical relation proposed by Guntherschultz and Betz ${ }^{4}$

$$
\mathrm{i}_{\mathrm{i}}=\mathrm{A}_{\mathrm{i}} \exp \left[\mathrm{B}_{\mathrm{i}} \mathrm{F}\right]
$$

The temperature dependent constants $A_{i}$ and $B_{i}$ were found. Comparing with CabreraMott equation ${ }^{27}$

Where,

$$
\mathrm{i}_{\mathrm{i}}=\operatorname{nvq} \cdot \exp [(-\mathrm{W}-\mathrm{qaF}) / \mathrm{k} \mathrm{T}]
$$

$\mathrm{n}$ is the number of mobile ions ; $\mathrm{q}$ is the charge of the mobile ion ; 
$v$ is the vibrational frequency $; \mathrm{F}$ is the field acting upon a mobile ion

$\mathrm{K}$ is the Boltzmann Constant $\quad ; \mathrm{T}$ is the absolute temperature

With equation (1) the expressions for $A_{i}$ and $B_{i}$ can be written as

$$
\begin{gathered}
\mathrm{A}_{\mathrm{i}}=\text { nvq.exp[-W/kT] } \\
\mathrm{B}_{\mathrm{i}}=\mathrm{qa} / \mathrm{kT}
\end{gathered}
$$

\begin{tabular}{|c|c|c|c|c|c|}
\hline $\begin{array}{c}\text { Current } \\
\text { density, i, } \\
\text { mA.cm }\end{array}$ & $\begin{array}{l}\text { Formation rate, } \\
\qquad \mathrm{dv} / \mathrm{dt}, V s^{-1}\end{array}$ & $\begin{array}{c}\text { Current } \\
\text { efficiency, } \\
\eta \%\end{array}$ & $\begin{array}{c}\text { Ionic current } \\
\text { density, } \mathrm{i}_{\mathrm{i}} \text {, } \\
\text { mA.cm }\end{array}$ & $\begin{array}{c}\text { Log. Ionic } \\
\text { current } \\
\text { density, } \log \mathrm{i}_{\mathrm{i}}\end{array}$ & $\begin{array}{l}\text { Differential } \\
\text { field, F.D, } \\
\text { MV.cm }\end{array}$ \\
\hline 4 & 0.78 & 26 & 1.04 & 0.017 & 6.51 \\
\hline 6 & 1.14 & 36 & 2.16 & 0.334 & 6.83 \\
\hline 8 & 1.60 & 45 & 3.64 & 0.561 & 7.02 \\
\hline 10 & 1.94 & 51 & 5.10 & 0.707 & 7.16 \\
\hline 12 & 2.35 & 58 & 7.02 & 0.846 & 7.34 \\
\hline
\end{tabular}

Table 2. Data on the anodization of $\mathrm{Zr}-2$ in $0.1 \mathrm{M}$ sulphamic acid.

Table 3. Data on the anodization of $\mathrm{Zr}-2$ in $0.1 \mathrm{M}$ ammonium hydroxide.

\begin{tabular}{cccccc}
\hline $\begin{array}{c}\text { Current } \\
\text { density, } \mathrm{i}, \\
\mathrm{mA.cm}-2\end{array}$ & $\begin{array}{c}\text { Formation rate, } \\
\mathrm{dv} / \mathrm{dt}, V s^{-1}\end{array}$ & $\begin{array}{c}\text { Current } \\
\text { efficiency, } \eta, \%\end{array}$ & $\begin{array}{c}\text { Ionic current } \\
\text { density, } \mathrm{i}_{\mathrm{i}}, \\
\mathrm{mA.cm}\end{array}$ & $\begin{array}{c}\text { log. Ionic } \\
\text { current } \\
\text { density, logi }\end{array}$ & $\begin{array}{c}\text { Differential } \\
\text { field, F.D }\end{array}$ \\
\hline 4 & 0.44 & 37 & 1.48 & 0.170 & 5.785 \\
6 & 0.77 & 40 & 2.40 & 0.380 & 6.025 \\
8 & 1.12 & 43 & 3.44 & 0.536 & 6.189 \\
10 & 1.62 & 47 & 4.70 & 0.672 & 6.350 \\
12 & 2.12 & 52 & 6.24 & 0.795 & 6.542 \\
\hline
\end{tabular}

\begin{tabular}{|c|c|c|c|c|c|}
\hline $\begin{array}{c}\text { Current } \\
\text { density, i, } \\
\text { mA.cm -2 }\end{array}$ & $\begin{array}{l}\text { Formation rate, } \\
\quad \mathrm{dv} / \mathrm{dt}, V s^{-1}\end{array}$ & $\begin{array}{c}\text { Current } \\
\text { efficiency, } \eta, \%\end{array}$ & $\begin{array}{c}\text { Ionic current } \\
\text { density, } \mathrm{i}_{\mathrm{i}} \text {, } \\
\text { mA.cm }^{-2}\end{array}$ & $\begin{array}{c}\log \text {. Ionic } \\
\text { current density, } \\
\log _{i_{i}}\end{array}$ & $\begin{array}{l}\text { Differential } \\
\text { field, F.D, } \\
\text { MV. cm }{ }^{-1}\end{array}$ \\
\hline 4 & 0.57 & 39.00 & 1.56 & 0.193 & 5.300 \\
\hline 6 & 1.01 & 45.50 & 2.70 & 0.431 & 6.026 \\
\hline 8 & 1.51 & 48.75 & 3.90 & 0.591 & 6.542 \\
\hline 10 & 2.04 & 54.00 & 5.40 & 0.732 & 6.960 \\
\hline 12 & 2.65 & 62.40 & 7.48 & 0.873 & 7.387 \\
\hline
\end{tabular}

Table 4. Data on the anodization of $\mathrm{Zr}-2$ in $0.1 \mathrm{M}$ potassium malonate.

The value of half-jump distance, 'a' deduced in $0.1 \mathrm{M}$ solutions of sulphamic acid and ammonium hydroxide electrolytes for zircaloy-2 are larger than the mean separation of oxygen ion in $\mathrm{ZrO}_{2}\left(1.66{ }^{0} \mathrm{~A}\right)$. The value of ' $\mathrm{a}$ ' is less in $0.1 \mathrm{M}$ potassium malonate for zircaloy-2. The high value of ' $a$ ' found in the case of sulphamic acid and ammonium hydroxide could probably be due to the migration of oxygen ions via interstices, grain boundaries etc. in which case the mean jump distance could be more than the interatomic distance. The values of $A_{i}, B_{i}, W$ and a are deduced for zircaloy- 2 in $0.1 \mathrm{M}$ sulphamic acid, $0.1 \mathrm{M}$ ammonium hydroxide and $0.1 \mathrm{M}$ potassium malonate Table 5 .

The differences in the field of formation to grow films ${ }^{28}$ on zirconium at a constant current density were observed in different electrolytes ${ }^{4,29-31}$. Radio tracer and Infrared absorption studies have shown that the anions are incorporated as such in the films ${ }^{32-35}$ and that the nature and concentration of the anions has a marked influence on the ionic and 
electronic conductivity of the films ${ }^{34-36}$. Such anions have been found to be absorbed as a consequence of anodization process and concentrate in the outer layers of the film. They affect the percentage ionic current density and hence the energy barrier for ionic movement ${ }^{34,35,37}$. These observations support the present results.

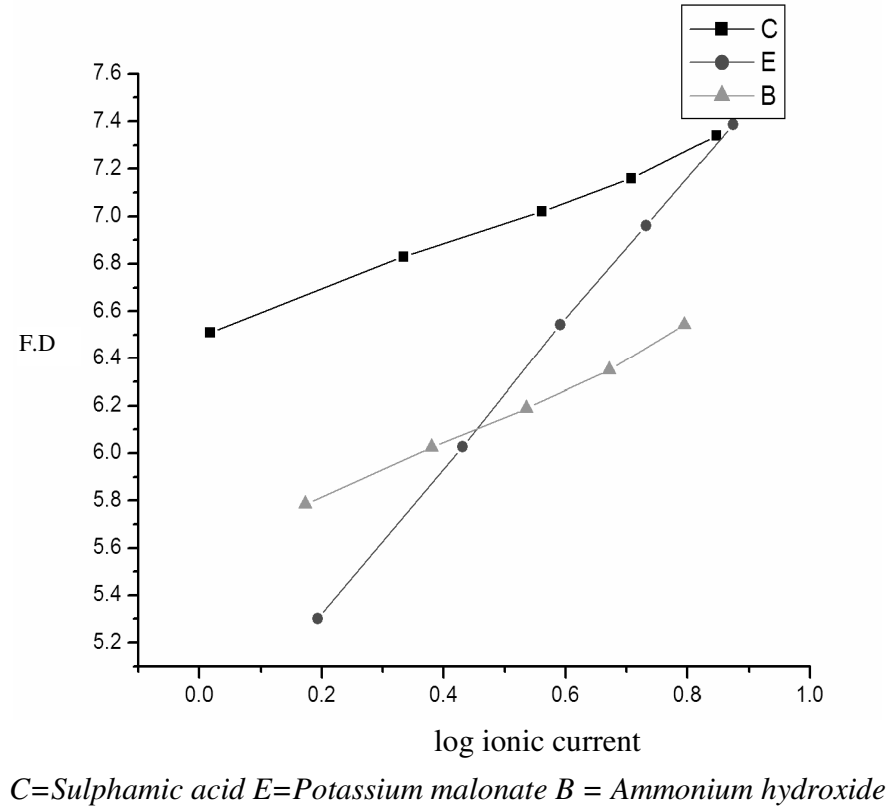

Figure 2. Variation of $\log$ ionic current density $\left(\log \mathrm{i}_{\mathrm{i}}\right)$ with differential field (F.D).

Table 5. Anodization of $\mathrm{Zr}-2$ in $0.1 \mathrm{M}$ solutions. Estimation of kinetic parameters of high field ion conduction_Control by oxide/ Electrolyte barrier).

\begin{tabular}{ccccc}
\hline $\begin{array}{c}\text { Electrolyte, } \\
0.1 \mathrm{M}\end{array}$ & $\mathrm{Ai}, \mathrm{mA} . \mathrm{cm}^{-2}$ & $\mathrm{Bi}, \mathrm{cm}^{-\mathrm{V}^{-1}}$ & $\begin{array}{c}\text { Height of the energy } \\
\text { barrier, W, eV }\end{array}$ & $\begin{array}{c}\text { Half jump } \\
\text { distance, a, }{ }^{0} \mathrm{~A}\end{array}$ \\
\hline $\begin{array}{c}\text { Sulphamic acid } \\
\text { ammonium } \\
\text { hydroxide }\end{array}$ & $1.267 \times 10^{-11}$ & $2.77 \times 10^{-6}$ & 1.20 & 3.58 \\
$\begin{array}{c}\text { Potassium } \\
\text { malonate }\end{array}$ & $2.933 \times 10^{-8}$ & $2.06 \times 10^{-6}$ & 1.04 & 2.67 \\
\hline
\end{tabular}

$A_{i}$ and $B_{i}$ are temperature dependent constants.

Nageshwar Rao ${ }^{38}$ obtained a value of $2.81 \times 10^{-6} \mathrm{cmV}^{-1}$ for $\mathrm{B}_{\mathrm{i}}$ and deduced the value of $3.65{ }^{0} \mathrm{~A}$ for ' $\mathrm{a}$ ' $[\mathrm{q}=2 \mathrm{e}]$. He also obtained a value of $2.6 \times 10^{-9} \mathrm{Acm}^{-2}$ for $\mathrm{A}_{\mathrm{i}}$ and deduced a value of $1.086 \mathrm{eV}$ for ' $\mathrm{W}$ ' in $0.1 \mathrm{M}$ sodium salicylate for zircaloy-2. The values obtained for zircaloy-2 in $0.1 \mathrm{M}$ solutions of sulphamic acid, ammonium hydroxide \& potassium malonate are comparable with the results of earlier workers ${ }^{38-42}$ more over the values of the kinetic parameters ' $a$ ' and ' $W$ ' obtained in the present work are comparable with the values for zirconium and its alloys .

Young et $a l^{10}$ found that the variation observed in ' $\mathrm{W}$ ' was largely due to the variation in ' $a$ ' value. He further reported that the value ' $W$ ' increase with the increase in ' $a$ ' value. These observations support the present work results 


\section{Conclusions}

The kinetic results are seen to have improved with zircaloy-2 in sulphamic acid and ammonium hydroxide as compared to the case in potassium malonate. Log-log relationships are found between the formation rate and current density. An exponential dependence of ionic current density on differential field was observed. The variations in half-jump distance and height of energy barrier are explained in terms of movement of mobile ions via interstices and grain boundaries

\section{Acknowledgements}

The authors are grateful to Prof. Zubeida Azeem, Principal, University College for Women, Osmania University. The authors are also grateful to Prof. K. S. S. Sastry for helpful discussions through out this work. One of the authors (VJJ) wishes to thank Dr. M Surekha Reddy, Head, Department of Chemistry, RBVRR Women's College. The authors are also thankful to Nuclear Fuel Complex, Hyderabad for generous help in providing zircaloy-2 sample.

\section{References}

1. Mclean Proceedings of the National Electronics Conference, Chicago, U.S.A, 1960, 206.

2. Wilcock W L, Emberson D L and Weekley B, Inst Radio Engs Trans Nucl Science, 1960, NS-7, 126.

3. Aladjem A, J Mater Sci., 1973, 8, 688.

4. Guntherschultze A and Betz H, ElectrolytKondensatoran, $2^{\text {nd }}$ Ed., Berlin, Herbert Cram., 1952.

5. Lakhiani D M and Sherier L L, Nature, 1960, 49, 188.

6. Aparna N S S, Nageshwar Rao B and Anjaneyulu Ch, Bulletin of Electrochemistry, 2006, 22(5), 235-239.

7. Raghunath Reddy G, Lavanya A and Anjaneyulu Ch, Bulletin of Electrochemistry, 2004, 20(8), 337-341.

8. Shobha T and Anjaneyulu Ch, J Electrochemical Society of India, 1991, 40(3),141-143.

9. Hoar T P, Modern Aspects of Electrochemistry, Butterworths, London, 1959, 2, Ch-4.

10. Young L, Grouk W S and Zobel F G R, Modern Aspects of Electrochemistry, Butterworth's, London, 1966, 4, Ch - 3

11. Vermilyea D A, Advances in Electrochemistry 4 Electrochemical Engineering, Interscience, New York, 1963, 3, 211.

12. Diggle J W, Downie T C and Goulding C W, Chem Rev., 1969, 69, 365.

13. Panasa Reddy A and Bhaskar Reddy, Transactions of SAEST, 2005, 40(4), 118-119.

14. Lavanya A, Raghunath Reddy G and Anjaneyulu Ch, Bulletin of Electrochemistry, 2004, 20(7), 305-308.

15. Ashok Kumar V, Raghunath Reddy $\mathrm{G}$ and Anjaneyulu Ch, Bulletin of Electrochemistry, 2005, 21(4), 17-21.

16. Raghunath Reddy G and Anjaneyulu Ch, Bulletin of Electrochemistry., 2003, 19(10), 471-475.

17. Raghunath Reddy G and Anjaneyulu Ch, Bulletin of Electrochemistry, 2002, 18(4), 187-192.

18. Shobha T, Sharma C S N, Shastry K S and Anjaneyulu Ch, Bulletin of Electrochemistry, 2001, 17(11), 519-522. 
19. Adams G B, Van Rysellberghe P and Moraghini M, J Electrochem Soc., 1955, 102, 502.

20. Adams G B, Lee T S, Draganov S M and Van Kysselberghe P, J Electrochem Soc., $1958, \mathbf{1 0 5}, 660$.

21. Willis G C Jr., Adams G M and Van Rysselberghe P, Electrochem Acta, 1964, 9, 79.

22. Wills G.C Jr, Adams G M and Van Rysselberghe P Electrochem Acta, 1964, 9, 93.

23. Ammar I A and Kamal I, Electrochim Acta, 1971, 16, 1539.

24. Lavrenko V and Chekhovskii A, Ukr Khim Zh., 1964, 30, 788.

25. Anjaneyulu Ch, Ph.D Thesis, Osmania University, 1981.

26. Shyamala Devi K, Anjaneyulu Ch and Shastry K.S, J Electrochem Soc India, 1986, 35, 29.

27. Cabrera N and Mott N F, Rept Prog Phys., 1948-49, 12,163.

28. Adams G B, Borchers C E and Van Rysselberghe P, A.E.C.U., 1957, 3432.

29. Young L, Anodic Oxide Films, Academic Press, Dordo, 1961.

30. Boltcher C J F, Theory of Dielectric Polarization, Elsevier, Amsterdam, 1952.

31. Cotron J B, Wood A C, Trans Inst Chem Eng., 1963, 41, 11.

32. Sastry K S, Ph.D. Thesis, Chelsea College,University of London, London, 1971.

33. Maraghini M, Serra N and La Ricerea, Scientifica, 1957, 27, 2468.

34. Maraghini M, Serra N and La Ricerea, Scientifica, 1959, 29, 2201.

35. Banter J C, J Electrochem Soc., 1967, 114, 108.

36. Johnson H A, Adams G B and Van Rysselberghe P, J Electrochem Soc., 1957, 104,339.

37. Maraghini T and Moriya, Proc Int Cong Met Corros., 1974, 322.

38. Nageshwar Rao B, Ph.D.Thesis, Osmania University, 1990.

39. Narayana M L, Ph.D.Thesis, Osmania University, 1980.

40. Nehru Prasad K, Ph.D.Thesis, Osmania University, 1992.

41. Lavanya A, Ph.D.Thesis, Osmania University, 2006.

42. Krishnaiah S, Ph.D.Thesis, Osmania University, 1993. 




International Journal of

Medicinal Chemistry



Carbohydrate Chemistry

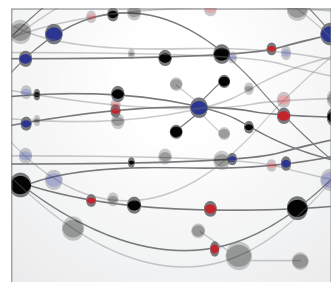

The Scientific World Journal

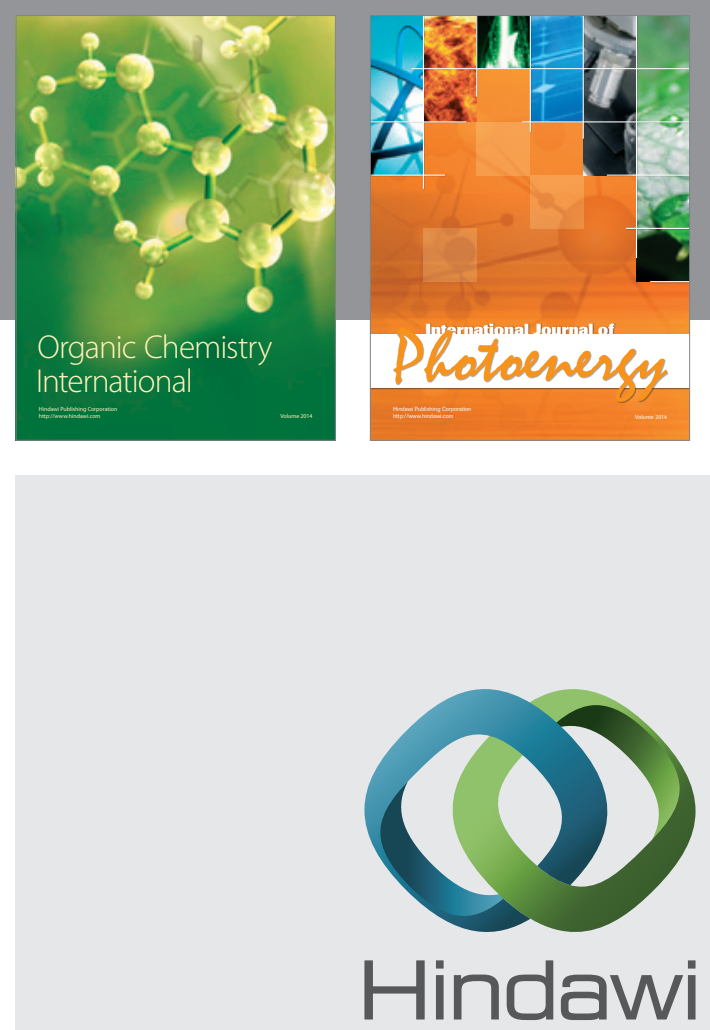

Submit your manuscripts at

http://www.hindawi.com
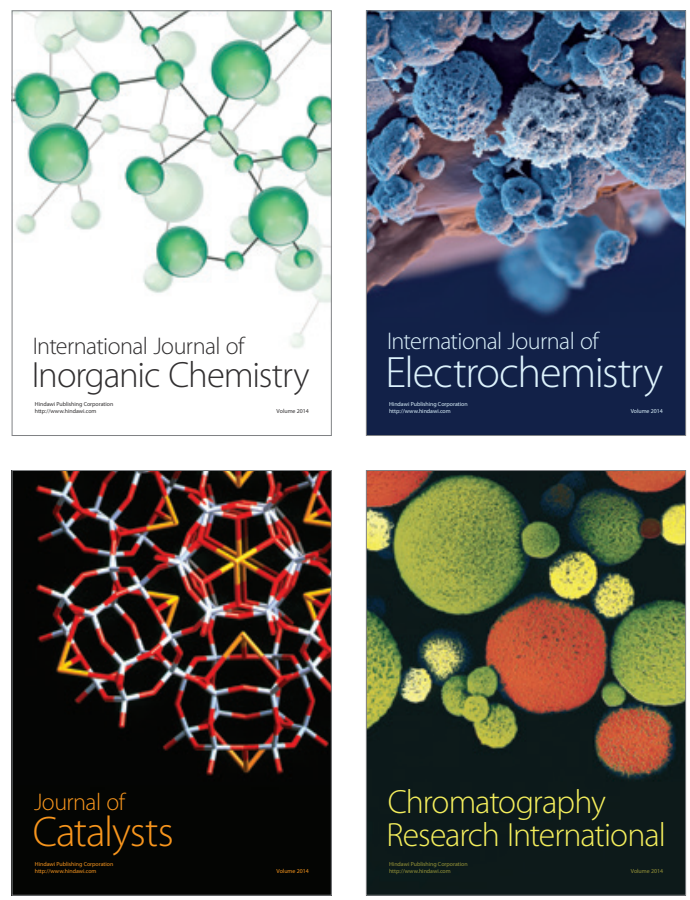
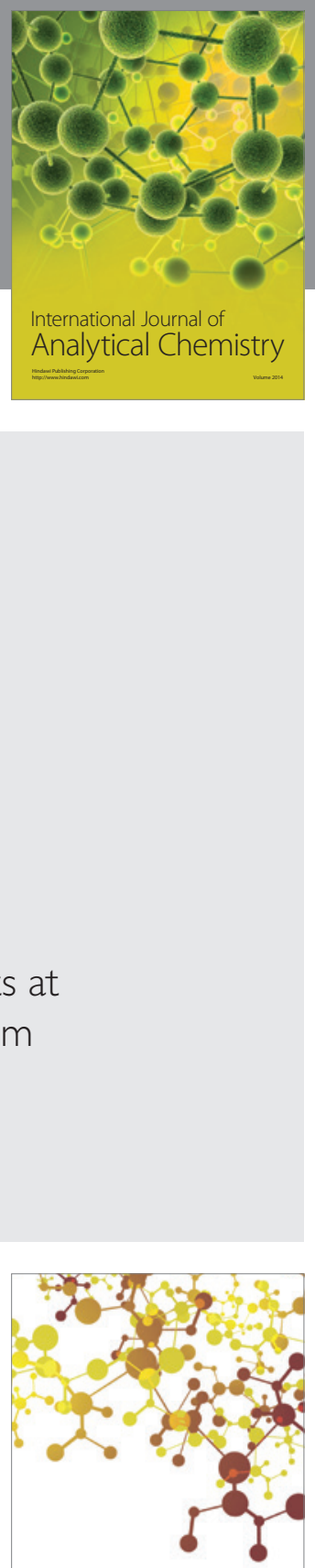

Journal of

Applied Chemistry
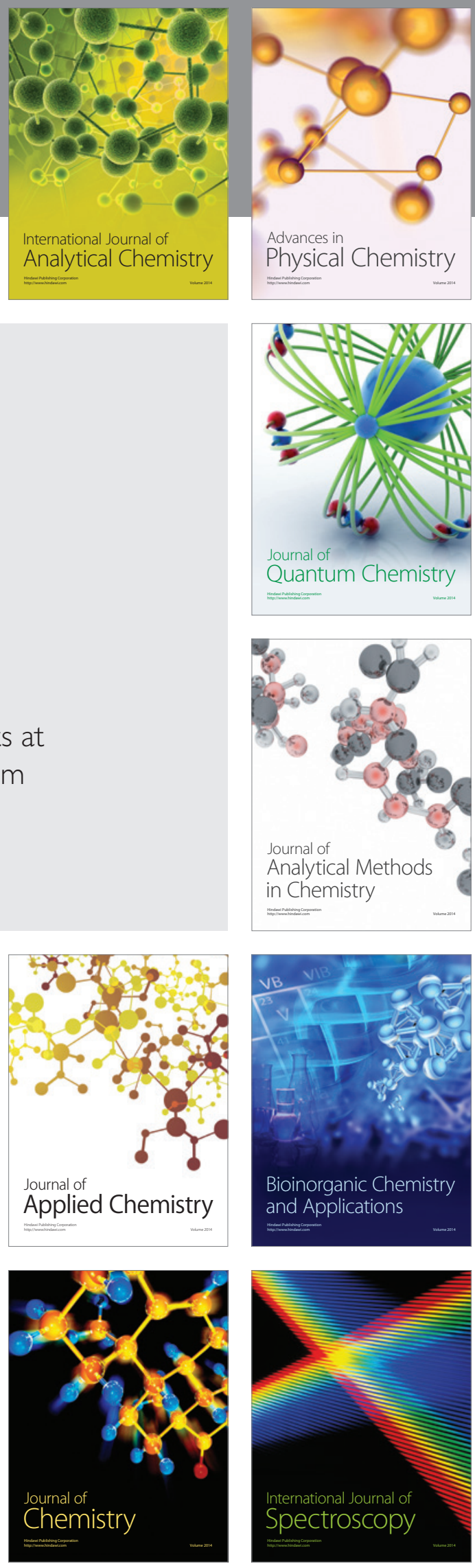